\title{
PENGARUH PENGURANGAN RANSUM PAKAN SECARA PERIODIK TERHADAP PERTUMBUHAN, SINTASAN, DAN PRODUKSI UDANG VANAME (Litopenaeus vannamei) POLA SEMI-INTENSIF DI TAMBAK
}

\author{
Abdul Mansyur, Hidayat Suryanto Suwoyo, dan Rachmansyah \\ Balai Riset Perikanan Budidaya Air Payau \\ Jl. Makmur Daeng Sitakka No. 129, Maros 90512, Sulawesi Selatan \\ E-mail: litkanta@indosat.net.id
}

(Naskah diterima: 3 April 2010; Disetujui publikasi: 1 April 2011)

\begin{abstract}
ABSTRAK
Pakan merupakan biaya produksi tertinggi dalam budidaya udang vaname di tambak, sehingga diperlukan informasi strategi manajemen pakan dalam budidaya. Tujuan penelitian adalah mengetahui pengaruh pengurangan ransum pakan secara periodik terhadap pertumbuhan, sintasan, produksi, rasio konversi pakan dan efesiensi pakan pada budidaya udang vaname pola semi-intensif. Penelitian dilakukan di tambak percobaan Punaga Takalar, menggunakan 6 petak pembesaran udang vaname masingmasing berukuran $4.000 \mathrm{~m}^{2}$. Hewan uji adalah pasca larva udang vaname dengan bobot awal rata-rata $0,017 \mathrm{~g}$ yang ditebar pada tambak dengan kepadatan $20 \mathrm{ekor} / \mathrm{m}^{2}$. Rancangan penelitian adalah rancangan acak lengkap dengan tiga perlakuan yang masing-masing perlakuan terdiri atas dua ulangan. Perlakuan yang diujicobakan adalah pengurangan ransum pakan (pemuasaan) secara periodik yaitu: A) pengurangan ransum pakan $30 \%$, B) pengurangan ransum pakan 60\%, dan C) kontrol (tanpa pengurangan ransum pakan). Hasil penelitian menunjukkan bahwa pengurangan ransum pakan secara periodik berpengaruh tidak nyata $(P>0,05)$ terhadap pertambahan bobot mutlak, laju pertumbuhan harian, sintasan, produksi, dan rasio konversi pakan bahkan mampu meningkatkan efisiensi pakan sekitar 7,71-22,39\%. Penghematan penggunaan pakan untuk udang vaname dapat dilakukan dengan pengurangan ransum pakan hingga $60 \%$ bobot badan/hari/minggu.
\end{abstract}

KATA KUNCl: tambak, vaname, produksi, manajemen pakan

ABSTRACT: The effect of gradual decrease of feed on the growth, survival rate and production rate of white shrimp (Litopenaeus vannamei) cultured in brackishwater pond using semi intensive technology. By: Abdul Mansyur, Hidayat Suryanto Suwoyo, and Rachmansyah

Feed cost accounts as the highest production cost in white shrimp culture. Therefore, an efficient strategy and management of feeding in the aquaculture is necessary. The objective of the research was to study the effect of gradual decrease of feed amount on the growth, survival rate, production, feed conversion ratio and feed efficiency rate of white shrimp (Litopenaeus vannamei) cultured in brackishwater pond using semi intensive technology. The research was conducted at Punaga Research Station, Takalar Regency using 6 ponds with 4,000 $\mathrm{m}^{2}$ stoked post larva vannamei with the average weight of 0.017 at stoking density of $20 \mathrm{ind} . / \mathrm{m}^{2}$. The experiment employed completely randomized design with 3 treatments and two 
replications for each treatment which were: $A) 30 \%$ decrease in feed, B) $60 \%$ decrease in feed, and C) control (without feed reduction). The results showed that the gradual decreases of feed amounts were not significantly different $(P>0.05)$ in affecting the absolute growth, daily growth rate, survival rate, production and feed conversion ratio of cultured white shrimp. The results offers the possibility of increasing feed efficiency up to $7.71-22.39 \%$. It is recomended that the efficiency of feeding rate of white shrimp can be obtained through a decrease of feed amount up to 60\%/body weight/day/week.

\section{KEYWORDS: brackishwater pond, Litopeneus vannamei, production, starvasion}

\section{PENDAHULUAN}

Saat ini teknologi budidaya udang vaname berkembang pesat diduga karena benih masih dapat ditebar dengan kepadatan lebih tinggi per hektar, serta memiliki sintasan dan produksi yang tinggi (Anonim, 2003; Poernomo, 2004). Namun penerapannya terbatas pada golongan masyarakat menengah keatas. Di Indonesia kepadatan tebar udang vaname yang umum dilakukan di berbagai daerah berkisar $80-100$ ind./ $/ \mathrm{m}^{2}$ dan dapat ditingkatkan hingga 244 ind./ $\mathrm{m}^{2}$, dan bila menggunakan probiotik mampu menghasilkan panenan 37,5 ton/ha/siklus (Poernomo, 2004). Melihat produksi yang tinggi akan berdampak kepada beban limbah yang dihasilkan baik oleh sisa pakan apabila rasio konversi pakan (FCR) tinggi, maupun kotoran udang. Di samping itu, produksi yang tinggi kadang tidak diikuti dengan keuntungan yang tinggi pula. Dari hasil analisis usaha budidaya udang vaname secara intensif dan semi intensif menunjukkan bahwa biaya produksi tertinggi adalah pakan yang berkisar $44 \%$. Tingginya biaya pakan antara lain disebabkan karena FCR cenderung meningkat. Menurut Akiyama \& Chwang (1989), untuk budidaya udang windu faktor yang mempengaruhi rasio konversi pakan adalah kualitas dan pengelolaan pakan selama pemeliharaan seperti pendugaan sintasan, dosis dan waktu pemberian pakan. Dampak lain dari FCR yang tinggi adalah menyebabkan air media dapat tercemar akibat akumulasi sisa pakan dan ekskresi ammonia dengan cepat. Dalam hal ini diperlukan cara penanggulangan baik melalui pengurangan akumulasi sisa pakan maupun pengurangan ekskresi.

Pengurangan ransum pakan secara periodik (pemuasaan) diduga merupakan salah satu cara yang dapat digunakan untuk menurunkan laju metabolisme maupun akumulasi sisa pakan. Pada hewan air, penurunan metabolisme dapat memberikan dua keuntungan yaitu penurunan konsumsi makanan dan pengurangan pencemaran air media melalui pengurangan ekskresi amonia. Namun tentu saja penurunan metabolisme juga akan mempengaruhi pertumbuhan dan sintasan. Karena itu pemuasaan dengan pengurangan ransum pakan udang vaname perlu dikaji untuk mempertahankan air media tetap baik tanpa menurunkan laju pertumbuhan, sintasan, produksi, dan peningkatan efesiensi pakan serta rendahnya FCR.

\section{BAHAN DAN CARA}

Penelitian dilakukan di tambak percobaan Punaga Takalar. Menggunakan 6 petak pembesaran udang vaname masing-masing berukuran $4.000 \mathrm{~m}^{2}$. Percobaan dilakukan menggunakan rancangan acak lengkap (RAL) dengan 3 perlakuan yang masing-masing perlakuan terdiri atas dua ulangan. Perlakuan yang dicobakan adalah pengurangan ransum pakan (pemuasaan) yaitu A) 30\% bobot biomassa/minggu, B) $60 \%$ bobot biomassa/ minggu, dan C) kontrol (tanpa pengurangan ransum pakan). Benur vaname yang ditebar adalah benur SPF atau bebas White Spot Syndrome Virus (WSSV) dan Taura Syndrome Virus (TSV) berdasarkan pengamatan Spesifik Pathogen Free (PCR).

Pelaksanaan penelitian dimulai dengan persiapan petakan tambak sesuai dengan protap persiapan budidaya udang yaitu: pengeringan/pengolahan tanah dasar dengan sempurna (nilai plus untuk redoks), pemberantasan hama dan pengapuran. Persiapan air untuk penebaran diupayakan dengan penumbuhan plankton sehingga perlu dilakukan pemupukan dasar (Urea + TSP). Pemeliharaan air ini berlangsung selama 3 minggu dan aplikasi probiotik 1 minggu sebelum penebaran. Bakteri dikultur dengan probiotik melalui proses fermentasi selama 3 hari dengan media tepung ikan, dedak halus, 
yeast, dan molase, serta air tambak yang sudah masak. Dosis dan metode media fermentasi sesuai dengan pedoman yang sudah ada (Poernomo, 2004) lalu ditebar ke tambak dengan dosis rata-rata 3,5-5,5 L/ha setiap minggu. Pemberian pakan komersil dimulai pada saat penebaran dengan dosis 2-100\% dan frekuensi 2-5 kali per hari. Perubahan jumlah pakan yang diberikan dilakukan setiap 15 hari sekali sesuai dengan hasil pengukuran bobot biomassa udang uji.

Parameter yang diamati adalah kualitas air meliputi: pH, suhu, DO, salinitas, alkalinitas, BOT, $\mathrm{NO}_{2}, \mathrm{NO}_{3}, \mathrm{PO}_{4}$ sedangkan pengamatan pertumbuhan dilakukan setiap 15 hari. Produksi, sintasan, dan FCR dihitung pada akhir penelitian dan dianalisis dengan perangkat statistik.

\section{HASIL DAN BAHASAN}

\section{Pertumbuhan, Sintasan, dan Produksi Udang Vaname}

Hasil pengamatan terhadap pertambahan bobot memperlihatkan bahwa pertambahan bobot udang vaname selama 96 hari pemeliharaan semakin meningkat seiring dengan meningkatnya waktu pemeliharaan untuk semua perlakuan (Gambar 1), tampak bahwa pertambahan bobot tertinggi diperoleh pada perlakuan $\mathrm{C}$ (tanpa pengurangan ransum pakan= kontrol) sebesar 14,23 g kemudian disusul perlakuan B dan A masing-masing sebesar 10,96 g dan 9,20 g. Hasil analisis statistik ragam menunjukkan bahwa pengaruh pengurangan ransum pakan terhadap pertumbuhan mutlak udang vaname tidak memperlihatkan perbedaan yang nyata antar perlakuan $(P>0,05)$ (Tabel 1$)$. Hasil yang diperoleh pada percobaan ini tidak berbeda jauh dengan hasil yang diperoleh Tahe (2008) bahwa penghematan penggunaan pakan untuk udang vaname dapat dilakukan dengan pengurangan ransum pakan hingga $75 \%$ bobot biomassa per minggu.

Menurut Chatakondi \& Yant (2001), bahwa pemuasaan melalui pengurangan ransum pakan secara periodik merupakan cara untuk mengurangi asupan pakan tanpa mengurangi produk budidaya. Bahkan pemuasaan dapat meningkatkan produksi ikan lele, Ictalurus punctatus karena ikan yang mengalami pemuasaan dapat tumbuh setara dengan ikan yang diberi pakan secara normal (100\%). Efek pemuasaan secara periodik terhadap pertumbuhan udang/ikan sangat mempengaruhi kebutuhan energinya. Pada udang yang mengalami pemuasaan atau pengurangan ransum pakan secara periodik (perlakuan A dan B) tidak dapat memperoleh pakan secara terusmenerus, sehingga udang tersebut akan kelaparan dan dalam beberapa kali daur pemuasaan diduga udang tersebut dapat menyesuaikan kondisi fisiologisnya terhadap

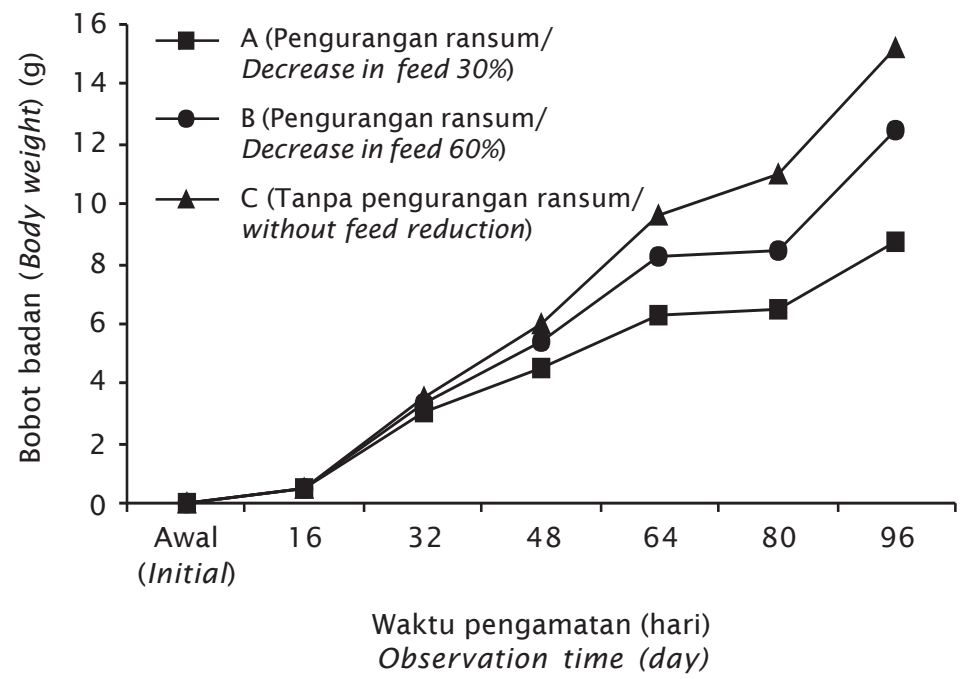

Gambar 1. Bobot rata-rata udang vannamei selama penelitian

Figure 1. Average body weight of L. vannamei during the experiment 
berkurangnya asupan pakan, sehingga mampu menghemat energi yang diperolehnya. Udang yang mengalami pemuasaan tersebut nampaknya menghemat energi dengan cara menurunkan aktivitas dan metabolisme rutin sebagaimana yang terjadi pada udang yang diberi pakan secara normal (perlakuan C).

Laju pertumbuhan bobot harian yang diperoleh pada penelitian ini (Tabel 1) berada pada kisaran $7,49-8,01 \%$. Hasil analisis ragam menunjukkan bahwa laju pertumbuhan bobot tertinggi diperoleh pada perlakuan kontrol dan tidak berbeda nyata $(P>0,05)$ dengan pengurangan ransum $30 \%$ dan $60 \%$. Laju pertumbuhan bobot harian udang vaname yang diperoleh dalam penelitian ini lebih baik dari penelitian Suwoyo \& Hendrajat (2006), yang memperoleh laju pertumbuhan harian udang vaname yang dipelihara pada substrat berbeda yakni pasir pantai, tanah sawah, dan tanah tambak masing-masing 4,76; 3,84; dan 5,35\%/ hari. Namun lebih rendah dari penelitian Hendrajat \& Mangampa (2007) yang mendapatkan laju pertumbuhan harian udang vaname pola tradisional plus dengan kepadatan 4, 6, dan 8 masing-masing 9,23; 9,19; dan 9,05\%/hari. Rachmansyah et al. (2006) memperoleh laju pertumbuhan harian udang vaname berkisar 9,48-9,52\%/hari selama 100 hari pemeliharaan. Arifin et al. (2007) memperoleh laju pertumbuhan harian udang vaname pola sederhana selama 60 hari pemeliharaan sebesar 14, 01\%. Perbedaan laju pertumbuhan yang diperoleh ini disebabkan perbedaan ukuran awal dan kepadatan udang yang ditebar, lama pemeliharaan serta wadah budidaya yang digunakan.

Hasil penelitian (Tabel 1) menunjukkan bahwa nilai rasio konversi pakan pada perlakuan pengurangan ransum pakan lebih tinggi $(1,34-1,37)$ dibandingkan dengan perlakuan kontrol/tanpa pengurangan ransum pakan $(1,24)$. Nilai rasio konversi pakan yang diperoleh pada penelitian ini tidak jauh berbeda dengan beberapa kajian budidaya udang vaname sebelumnya. Anonim (2003) mendapatkan FCR 1,3 untuk budidaya udang vaname dengan kepadatan 90 ekor $/ \mathrm{m}^{2}$, sintasan $70-90 \%$, dan bobot udang rata-rata saat panen $20 \mathrm{~g} /$ ekor dengan lama pemeliharaan 110 hari.

Haliman \& Adijaya (2005) melaporkan budidaya udang vaname di Situbondo, Jawa Timur dengan padat tebar 150 ekor $/ \mathrm{m}^{2}$, sintasan $85 \%$, bobot akhir 14,28 g/ekor, menghasilkan udang sebanyak $5.465 \mathrm{~kg} /$ $3.000 \mathrm{~m}^{2}$ dengan FCR 1,5 . Menurut Sutanto (2005), bahwa untuk meningkatkan efisiensi dalam budidaya udang vaname salah satu hal yang perlu dilakukan yakni menggunakan pakan yang berkualitas baik dan berprotein rendah (30\% protein) sehingga bisa mengurangi pencemaran/lebih ramah lingkungan, pengelolaan air lebih mudah, pertumbuhan lebih baik, FCR lebih rendah sehingga biaya pakan menjadi lebih rendah. Huet (1971) menyatakan bahwa konversi pakan dipengaruhi oleh sintasan, kepadatan, bobot individu, perbedaan persentase makanan harian, waktu dan lokasi penelitian serta pertumbuhan biomassa udang. Semakin rendah nilai konversi pakan semakin baik karena sedikit jumlah makanan yang dimanfaatkan untuk meningkatkan bobot udang.

Hasil analisis ragam menunjukkan bahwa pengurangan ransum pakan secara periodik selama pemeliharaan udang vaname tidak berpengaruh nyata terhadap rasio konversi pakan dan nilai efisiensi pakan $(P>0,05)$. Hal ini menunjukkan bahwa nilai rasio konversi pakan udang vaname yang dikurangi pakannya maupun tidak dikurangi pakannya relatif sama dan mampu meningkatkan efisiensi pakan sekitar 7,71-22,39\% dari perlakuan kontrol atau sekitar 72,42-74,74\%. Menurut Susilo et al. (2002), bahwa efisiensi pakan dapat dicapai bila pada pembesaran ikan/ udang memperhatikan manajemen pemberian pakan, sebab pakan yang dikonsumsi organisme budidaya pada gilirannya akan digunakan untuk tumbuh. Oleh karena itu, pakan yang kurang dari kebutuhan minimal organisme budidaya untuk mempertahankan bobot tubuh akan berakibat penurunan bobot akibat cadangan makanan dalam tubuh digunakan untuk memenuhi kebutuhan energi akitivitasnya. Wyban \& Sweeny (1991) mengemukakan bahwa pemberian pakan yang tepat baik kualitas maupun kuantitas dapat memberikan pertumbuhan yang optimum bagi udang. Pemberian pakan dalam jumlah yang berlebihan akan meningkatkan biaya produksi dan pemborosan serta menyebabkan sisa pakan yang berlebihan yang berakibat pada penurunan kualitas air sehingga berpengaruh pada pertumbuhan dan sintasan udang.

Berdasarkan Tabel 1, terlihat bahwa nilai produksi udang vaname yang diperoleh pada penelitian ini berkisar antara 712,95-832,75 
Tabel 1. Pertambahan bobot, laju pertumbuhan harian, rasio konversi pakan, efesiensi pakan, sintasan, dan produksi udang vaname pada masing-masing perlakuan selama penelitian

Table 1. Body weight gain, daily growth rate, feed conversion ratio, feeding effeciency, survival rate, and production of $L$. vannamei in each treatment during the experiment

\begin{tabular}{|c|c|c|c|}
\hline \multirow{2}{*}{$\begin{array}{l}\text { Peubah } \\
\text { Variable }\end{array}$} & \multicolumn{3}{|c|}{$\begin{array}{c}\text { Perlakuan pengurangan ransum pakan (\% BB/hari/minggu) } \\
\text { Gradual decrease of feed (\%BW/week) }\end{array}$} \\
\hline & $30 \%$ & $60 \%$ & Kont rol \\
\hline Kepadatan (ekor/m²) & 20 & 20 & 20 \\
\hline \multicolumn{4}{|l|}{ Stocking density (ind $/ \mathrm{m}^{2}$ ) } \\
\hline Lama pe meliharaan (hari) & 96 & 96 & 96 \\
\hline \multicolumn{4}{|l|}{ Rearing period (day) } \\
\hline Bobot Awal (g) & 0.017 & 0.017 & 0.017 \\
\hline \multicolumn{4}{|l|}{ Initial weight $(g)$} \\
\hline Bobot Akhir (g) & $9.22 \pm 0.424$ & $10.98 \pm 3.917$ & $14.25 \pm 0.297$ \\
\hline \multicolumn{4}{|l|}{ Final weight $(g)$} \\
\hline Pertumbuhan mutlak (g) & $9.20 \pm 0.424^{a}$ & $10.96 \pm 3.917^{a}$ & $14.23 \pm 0.297^{a}$ \\
\hline \multicolumn{4}{|l|}{ Absolute growth (g) } \\
\hline Laju pertumbuhan harian (\%) & $7.49 \pm 0.049^{a}$ & $7.66 \pm 0.431^{\mathrm{a}}$ & $8.01 \pm 0.028^{a}$ \\
\hline \multicolumn{4}{|l|}{ Daily growth rate (\%) } \\
\hline Rasio konversi pakan (FCR) & $1.34 \pm 0.127^{a}$ & $1.37 \pm 0.148^{a}$ & $1.24 \pm 0.092^{\mathrm{a}}$ \\
\hline \multicolumn{4}{|l|}{ Feed conversion ratio } \\
\hline Efisiensi pakan (\%) & $74.74 \pm 8.138^{\mathrm{a}}$ & $72.42 \pm 1.223^{\mathrm{a}}$ & $83.57 \pm 1.322^{\mathrm{a}}$ \\
\hline \multicolumn{4}{|l|}{ Feeding efficiency (\%) } \\
\hline Produksi (kg ) & $712.95 \pm 120.42^{\mathrm{a}}$ & $832.75 \pm 307.24^{a}$ & $970.00 \pm 327.39^{a}$ \\
\hline Production (kg) & & & \\
\hline
\end{tabular}

Nilai dalam baris yang sama diikuti huruf yang sama menunjukkan tidak berbeda nyata $(P>0,05)$ Values in the same row followed by the same superscript are not significantly different $(P>0.05)$

kg selama 96 hari pemeliharaan. Produksi tertinggi diperoleh pada perlakuan $\mathrm{C}$ (kontrol) yaitu $970 \mathrm{~kg}$, disusul perlakuan B (pengurangan ransum pakan $60 \%$ per minggu) yaitu $832,75 \mathrm{~kg}$ sedangkan pada perlakuan A (pengurangan ransum pakan $30 \%$ per minggu) adalah $712,95 \mathrm{~kg}$. Namun hasil analisis ragam menunjukkan bahwa pengurangan ransum pakan selama pemeliharaan udang vaname tidak berpengaruh nyata terhadap produksi udang $(P>0,05)$. Fenomena yang hampir sama juga dijumpai pada penelitian Cholik \& Ahmad (1981) bahwa starvasi sampai 48 jam tidak berpengaruh nyata terhadap pertambahan bobot, sintasan maupun produksi udang putih. Menurut Utojo et al. (1989) bahwa tinggi rendahnya produksi yang dihasilkan tergantung pada sintasan, kecepatan laju pertumbuhan, makanan, dan padat penebaran udang yang dipelihara.

\section{Kualitas Air}

Hasil pengamatan kualitas air yang meliputi salinitas, oksigen terlarut, $\mathrm{pH}$, alkalinitas, dan suhu air disajikan pada Tabel 2, sedangkan parameter lain seperti BOT, $\mathrm{NH}_{4}$ (Gambar $2 \mathrm{a}$ dan 2 b), $\mathrm{NO}_{2}, \mathrm{NO}_{3}$, dan $\mathrm{PO}_{4}$ (Gambar 3a, 3b, dan 3c).

Suhu air sebagai salah satu faktor pembatas utama adalah memegang peranan penting bagi kehidupan dan pertumbuhan udang. Kisaran hasil pengukuran suhu air untuk semua perlakuan selama penelitian adalah $\mathrm{A}(21,15-27,1){ }^{\circ} \mathrm{C} ; \mathrm{B}(21,99-27,60)^{\circ} \mathrm{C}$; dan $C(21,99-27,60)^{\circ} \mathrm{C}$ (Tabel 2). Menurut Cholik (1988), kisaran suhu yang terbaik untuk pertumbuhan dan kehidupan udang terletak pada suhu $28-30^{\circ} \mathrm{C}$, namun masih dapat hidup pada suhu $18-36^{\circ} \mathrm{C}$, di mana pada tingkat suhu air $36^{\circ} \mathrm{C}$ udang sudah tidak aktif. Berdasarkan 
Tabel 2. Kisaran nilai beberapa parameter kualitas air tambak budidaya udang vaname semiintensif

Table 2. The range values of water quality parameters in the semi intensive pond of cultured $L$. vannamei during the experiment

\begin{tabular}{lccc}
\hline \multirow{2}{*}{ Paramet er } & \multicolumn{3}{c}{ Nilai kisaran (Range values) } \\
\cline { 2 - 4 } & A & B & C \\
\hline Suhu air (Water temperature) $\left({ }^{\circ} \mathrm{C}\right)$ & $21.15-27.1$ & $21.99-27.6$ & $21.99-27.6$ \\
Oksigen terlarut $($ Dissolved oxygen $)(\mathrm{mg} / \mathrm{L})$ & $2.7-7.60$ & $3.0-7.95$ & $3.4-8.40$ \\
$\mathrm{pH}$ air $($ Water $p H)$ & $7.0-10$ & $7.0-10$ & $7.0-10$ \\
Alkalinitas $($ Alkalinity) $(\mathrm{mg} / \mathrm{L})$ & $104.27-60.72$ & $111.93-152.11$ & $100.45-149.24$ \\
Salinitas (Salinity) $(\mathrm{ppt})$ & $22.5-42.5$ & $23-43.5$ & $29.5-45.5$ \\
\hline
\end{tabular}

A. Pengurangan ransum 30\% (30\% decrease in feed), B. Pengurangan ransum $60 \%$ (60\% decrease in feed), C. Tanpa pengurangan ransum (Without feed reduction)

keterangan diatas menunjukkan suhu pada penelitian ini masih layak untuk kehidupan udang vaname.

Derajat keasaman air penting untuk menentukan nilai guna perairan bagi perikanan. Menurut Swingle (1968), bahwa umumnya batas toleransi jasad ikan dan jasad makanannya terhadap derajat keasaman berkisar antara 4,0-11,0. Hasil pengamatan $\mathrm{pH}$ pada penelitian ini adalah berkisar 7,5-10,0 (Tabel 2). Berdasarkan hal tersebut diatas maka $\mathrm{pH}$ perairan penelitian masih dalam toleransi udang vaname.

Oksigen merupakan parameter mutu air yang penting bagi kehidupan biota perairan. Perubahan kadar oksigen yang drastis dapat menimbulkan kematian bagi biota perairan. Kisaran oksigen untuk kedua perlakuan selama penelitian berkisar 2,7-8,4 mg/L (Tabel 2). Konsentrasi oksigen tertinggi diperoleh pada saat aktivitas fotosintesis optimal oleh fitoplankton pada siang hari. Selanjutnya kandungan oksigen rendah pada saat pagi hari di mana aktivitas fotosintesis belum optimal. Menurut Boyd (1990), jika tidak ada senyawa beracun konsentrasi oksigen minimal $2 \mathrm{mg} / \mathrm{L}$ sudah cukup untuk mendukung kehidupan jasad perairan secara normal. Berdasarkan hal tersebut kandungan oksigen yang diperoleh dalam penelitian ini masih layak untuk kehidupan udang vaname. Pada penelitian ini, kisaran alkalinitas adalah 100,45-160,72 $\mathrm{mg} / \mathrm{L}$ (Tabel 2). Menurut Sticney (1979), alkalinitas yang baik untuk budidaya antara 30 dan $200 \mathrm{mg} / \mathrm{L}$.
Hasil pengukuran salinitas pada semua perlakuan selama penelitin adalah 22,5-45,5 ppt (Tabel 2). Fluktuasi salinitas tersebut karena akhir penelitian memasuki musim penghujan. Menurut Bardach et al. (1972), salinitas yang baik untuk pertumbuhan beberapa jenis udang berkisar antara 10-25 ppt. Dengan demikian salinitas pada penelitian ini masih dalam kisaran yang layak untuk mendukung pertumbuhan udang vaname.

Hasil pengamatan terhadap bahan organik total (BOT), amoniak (Gambar 2a dan 2b), nitrit, nitrat, dan fosfat (Gambar 3a, 3b, dan 3c). Berdasarkan Gambar 2a nampak bahwa kandungan bahan organik total (BOT) pada semua perlakuan berkisar antara 16,71-45,585 $\mathrm{mg} / \mathrm{L}$. Tinggi rendahnya kandungan BOT dipengaruhi oleh banyak sedikitnya limbah organik dari sisa pakan dan kotoran udang dan erat kaitannya dengan populasi bakteri probiotik maupun Vibrio sp. Pada kondisi tambak biasanya apabila kandungan BOT tinggi maka populasi Vibrio sp. akan meningkat, tetapi apabila keberadaan bakteri probiotik aktif berperan mengurai BOT, maka BOT menjadi rendah dan populasi Vibrio sp. juga rendah. Kandungan amoniak (Gambar 2b) tertinggi $0,1437 \mathrm{mg} / \mathrm{L}$ diperlakuan B pada hari ke-28 sedangkan pada perlakuan lain masih stabil. Setelah hari ke 70 perlakuan C (kontrol) mencapai $0,1053 \mathrm{mg} / \mathrm{L}$, selanjutnya pada akhir penelitian, konsentrasi amonia pada semua perlakuan terus menurun.

Kandungan $\mathrm{NO}_{2}-\mathrm{N}$ tertinggi $(0,06525 \mathrm{mg} /$ L) pada perlakuan B (Gambar 2a) pada hari ke- 

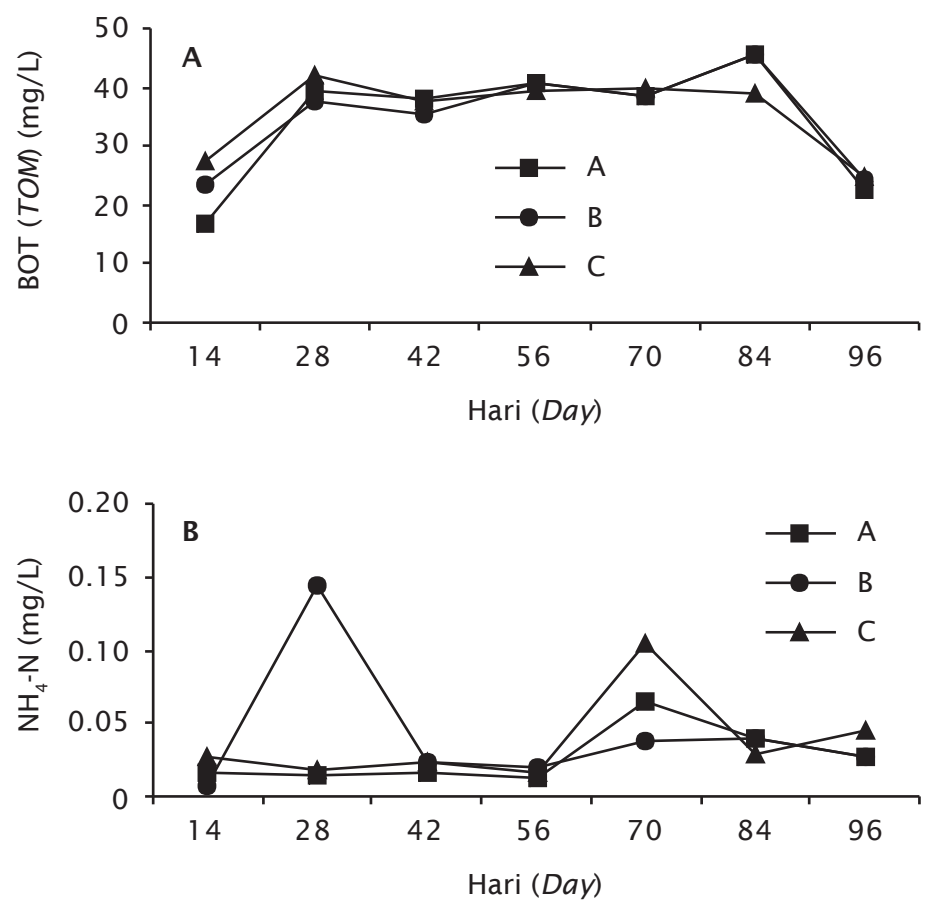

A) Pengurangan ransum 30\% (30\% decrease in feed), B) Pengurangan ransum $60 \%$ (60\% decrease in feed), C) Tanpa pengurangan ransum (Without feed reduction)

Gambar 2. Konsentrasi BOT (a), amoniak (b) pada budidaya udang vaname dengan pengurangan pakan berbeda

Figure 2. Concentration of total organic matter (TOM) (a), ammonium (b) in L. Vannamei culture pond treated with different feed applications

42 sedangkan perlakuan lain agak stabil, namun pada hari ke 96 konsentrasi amonia pada perlakuan A meningkat sampai pada level 0,0666 mg/L. Menurut Boyd (1990) kandungan nitrit yang aman di tambak pembesaran benur udang windu adalah $4,5 \mathrm{mg} / \mathrm{L}$ dan konsentrasi amonia $0,45 \mathrm{mg} / \mathrm{L}$ sudah dapat mengurangi laju tumbuh udang sebanyak $50 \%$.

Amoniak dalam air akan diubah menjadi nitrit oleh adanya aktivitas bakteri Nitrosomonas sp. dan selanjutnya nitrit akan segera diubah menjadi nitrat oleh aktivitas bakteri Nitrobactersp. Kondisi optimal untuk kedua proses tersebut adalah apabila jumlah oksigen mencukupi, kapasitas buffer, baik $\mathrm{pH}$ netral dan suhu air rendah.

Daya racun nitrit terhadap benih udang dipengaruhi oleh salinitas, Lin \& Chen (2003) melaporkan bahwa level yang aman kandungan $\mathrm{NO}_{2}-\mathrm{N}$ pada pemeliharaan benur Litopenaeus vannamei adalah 6,$1 ; 15,2$; dan $25,7 \mathrm{mg} / \mathrm{L}$ pada salinitas berturut-turut 15 ; 25; dan 35 ppt.

Nitrat relatif tinggi pada awal penebaran pada semua perlakuan dan kontrol namun pada akhir pemeliharaan, kandungan nitrat telah mengalami penurunan mungkin karena dimanfaatkan oleh plankton yang tumbuh di dalam petakan tambak. Pada penelitian ini konsentrasi nitrat pada level antara 0,0273$0,08445 \mathrm{mg} / \mathrm{L}$. Menurut Effendi (2003), bahwa kadar nitrat-N lebih dari $0,2 \mathrm{mg} / \mathrm{L}$ dapat mengakibatkan terjadinya eutrofikasi (pengkayaan nutrien) di perairan yang selanjutnya dapat menstimulir pertumbuhan algae secara cepat.

Konsentrasi fosfat pada awalnya relatif rendah di semua perlakuan, tetapi kemudian 

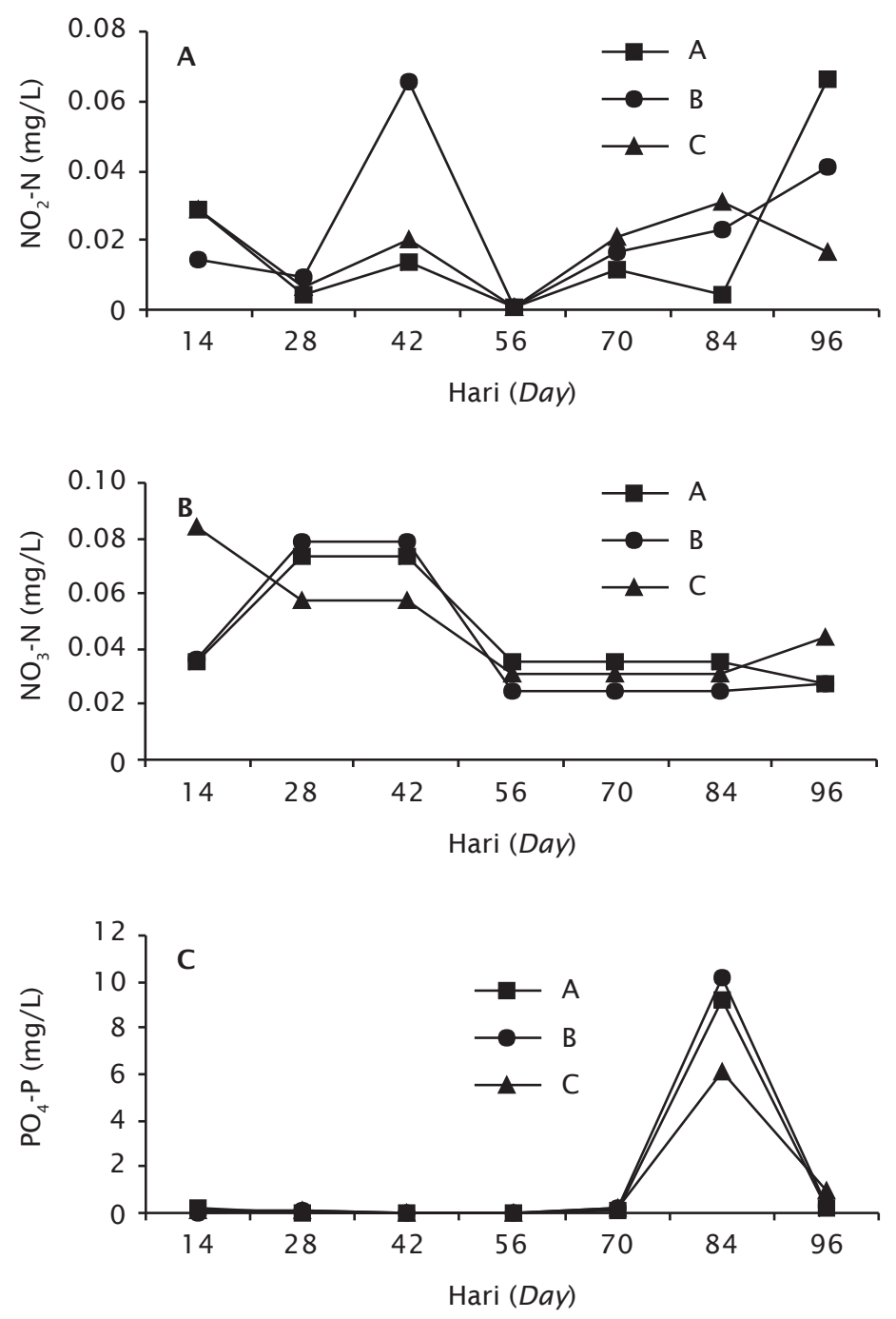

A) Pengurangan ransum 30\% (30\% decrease in feed), B) Pengurangan ransum $60 \%$ (60\% decrease in feed), C) Tanpa pengurangan ransum (Without feed reduction)

Gambar 3. Konsentrasi nitrit (a), nitrat (b), dan fosfat (c) pada budidaya udang vaname dengan pengurangan pakan berbeda

Figure 3. Concentration of nitrite (a), nitrate (b), and phosphate (c) in L. Vannamei culture pond treated with different feed applications

meningkat dengan semakin lama penelitian berlangsung. Terlihat pada semua perlakuan yakni pada hari ke-84 perlakuan $A=10,1492$ $\mathrm{mg} / \mathrm{L}, \mathrm{B}=9,2542 \mathrm{mg} / \mathrm{L}$, dan $\mathrm{C}=6,1498 \mathrm{mg} / \mathrm{L}$. $\mathrm{Hal}$ ini sesuai dengan pendapat Boyd (1999) bahwa sisa pakan, feses udang dan bahan organik lainnya didekomposisi oleh mikroorganisme menjadi nutrien anorganik seperti fosfat, amonia, dan karbondioksida. Peningkatan kandungan fosfat di air dapat meningkatkan populasi fitoplankton. Menurut Choo \& Tanaka (2000), bahwa kadar fosfat yang 
direkomendasikan supaya tidak terjadi eutrofikasi di pantai dan di laut adalah 0,0045 $\mathrm{mg} / \mathrm{L}$ dan 0,0015 mg/L. Dengan demikian konsentrasi fosfat pada penelitian ini melebihi konsentrasi fosfat yang direkomendasikan di perairan pantai dan hal ini jelas terlihat apabila air tambak dibuang terutama pada saat ganti air ataupun panen.

\section{KESIMPULAN DAN SARAN}

1. Starvasi melalui pengurangan ransum pakan secara periodik tidak mempengaruhi pertumbuhan, sintasan, dan produksi udang vaname

2. Pengurangan jumlah pakan yang dikonsumsi secara periodik mampu meningkatkan efisiensi pakan sekitar 7,71-23,39\% dibandingkan perlakuan kontrol atau sekitar $72,42-74,74 \%$ dengan nilai rasio konversi pakan yang rendah $(1,24-1,37)$

3. Penghematan penggunaan pakan untuk udang vaname tanpa merugikan kehidupannya dapat dilakukan dengan cara starvasi melalui pengurangan ransum pakan hingga $60 \% \mathrm{BB} /$ hari/minggu pada budidaya udang vaname semiintensif

\section{DAFTAR ACUAN}

Akyama, D.M. \& Chwang, N.L.M. 1989. Shrimp feed requirements and feed management. In Akiyama, D.M. (ed.). Proceeding of the Southeast Asia Shrimp Farm Management Workshop. American Soybean Association, Singapore, p. 75-82.

Anonim. 2003. Litopenaeus vannamei sebagai alternative budidaya udang saat ini. PT Central Proteinaprima (Charoen Pokphand Group) Surabaya, $16 \mathrm{hlm}$.

Arifin, Z., Andrat, V., \& Subiyanto. 2007. Teknik produksi udang vaname (Litopenaeus vannamei) secara sederhana. Departemen Kelautan dan Perikanan. Balai Besar Pengembangan Budidaya Air Payau Jepara, $9 \mathrm{hlm}$.

Bardach, J.E., Rither, J.H., \& McLarney, W.O. 1972. Aquaculture. The farming and husbandry of freshwater and marine organism. Wiley Interscience Pub., New York, 868 pp.

Boyd, C.F. 1990. Water quality in ponds for aquaculture. Auburn University, Alabama USA, 482 pp.

Boyd, C.E. 1999. Codes of practice for responsible shrimp farming. Department of fisheries and Allied Aquacultures, Auburn University, AL USA, $36 \mathrm{pp}$.
Chatakondi, N.G. \& Yant, R.D. 2001. Application of compestory growth to enchance production in channel catfish, Ictalurus punctatus. Journal of the World Aquaculture Society, 32: 278-285.

Cholik, F. 1988. Pengolahan mutu air tambak udang. Seminar Aquabisnis udang. Tanggal 19-20 Desember 1988. Dumai, Riau, p. 1-45.

Cholik, F., dan Ahmad, T. 1981. Studi pendahuluan pengaruh starvasi terhadap pertumbuhan dan produksi udang putih (Penaeus merguensis de Man). Bulletin Penelitian Perikanan. Majalah IImiah Perikanan Indonesia. Badan Penelitian dan Pengembangan Pertanian, 1(2): 209-217.

Choo, P.S. \& Tanaka, K. 2000. Nutrient levels in ponds during the grow-out and harvest phase of Penaeus monodon under semiintensive or intensive culture. JIRCAS Journal, 8: 13-20.

Effendi, H. 2003. Telaah kualitas air bagi pengelolaan sumber daya dan lingkungan perairan. Kanisius Yogyakarta, $258 \mathrm{hlm}$.

Haliman, R.W. \& Adijaya, D.S. 2005. Udang vannamei, Pembudidayaan dan Prospek Pasar Udang Putih yang Tahan Penyakit. Penebar Swadaya, Jakarta, 75 hlm.

Hendrajat, E.A. \& Mangampa, M. 2007. Pertumbuhan dan sintasan udang vaname (Litopenaeus vannamei) pola tradisional plus dengan kepadatan berbeda. J. Ris. Akuakultur, 2(2): 149-155.

Huet, M. 1971. Textbook of Fish Culture, Cyre and Sportis Woode Ltd, London, $436 \mathrm{pp}$.

Lin, Y.C. dan Chen, J.C. 2003. Acute toxicity of nitrite on Litopenaeus vannamei (boone) juveniles at different salinity levels. Aquaculture, 224: 193-201.

Poernomo, A. 2004. Teknologi Probiotik Untuk Mengatasi Permasalahan Tambak Udang dan Lingkungan Budidaya. Makalah disampaikan pada Simposium Nasional Pengembangan Ilmu dan Inovasi Teknologi dalam Budidaya. Semarang , 27-29 Januari. 2004, 24 hlm.

Rachmansyah., Suwoyo, H.S., Undu, M.C., \& Makmur. 2006. Pendugaan Nutrient Budget tambak intensif udang Litopenaeus vannamei. J. Ris. Akuakultur, 1(2): 181-202.

Sticney, R.R. 1979. Principles of warmwater aquaculture. John Wiley and Sons, New York, $375 \mathrm{pp}$.

Susilo, U., Hariyadi, B., \& Rachmawati, F.N. 2002. Laju tumbuh harian, laju makan, 
pemeliharaan tubuh dan efisiensi pakan ikan patin , Pangasius spp., pada frekuensi pemberian pakan berbeda. Sains Akuatik. Jurnal IImu-Ilmu Perairan. Fakultas Perikanan dan IImu Kelautan Universitas Muhammadiyah Purwokerto, 2(2): 33-37.

Sutanto, I. 2005. Kesuksesan budidaya udang vannamei (Litopenaeus vannamei) di Lampung. dalam A. Sudrajat, Z.I. Azwar, L.E. Hadi. Haryanti. N.A.Giri dan G.Sumiarsa. 2005. Buku Perikanan Budidaya Berkelanjutan. Pusat Riset Perikanan Budidaya. Badan Riset Kelautan dan Perikanan, hlm. 67-72.

Suwoyo, H.S. \& Hendrajat, E.A. 2006. Pemeliharaan udang vaname (Litopenaeus vannamei) pada substrat yang berbeda. Prosiding Seminar Akuakultur. Pusat Riset Perikanan Budidaya, Jakarta, $7 \mathrm{hlm}$.
Swingle, H.S. 1968. Standardization of Chemical Analisys for Water and Pond mud. FAO. Fish. Rep., 44(4): 397-406.

Tahe, S. 2008. Pengaruh starvasi ransum pakan terhadap pertumbuhan, sintasan, dan produksi udang vaname (Litopenaeus vannamei) dalam wadah terkontrol. J. Ris. Akuakultur, 3(3): 401-412.

Utojo, Cholik, F., Mansyur, A., \& Mangawe, A.G. 1989. Pengaruh padat penebaran terhadap pertumbuhan, daya kelulusan hidup dan produksi udang windu (Penaeus monodon) dalam keramba jaring apung di muara Sungai Binasangkara. Jurnal Penelitian Budidaya Pantai, Maros, 5(1): 95-101.

Wyban, J.A. \& Sweeny, J.N. 1991. Intensive Shrimp Production Technology. The Oceanic Institute Makapuu Point. Honolulu, Hawai USA, 158 pp. 